\title{
Reservoir properties of the Upper Rotliegend and the Weissliegend sandstones (Permian) in the Zielona Góra Basin (western Poland)
}

\author{
Anna POSZYTEK ${ }^{1, *}$ \\ 1 Institute of Geochemistry, Mineralogy and Petrology, Warsaw University, Żwirki i Wigury 93, 02-089 Warszawa, Poland
}

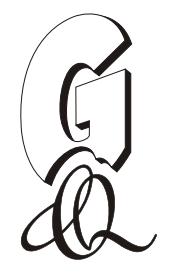

Poszytek A. (2014) Reservoir properties of the Upper Rotliegend and the Weissliegend sandstones (Permian) in the Zielona Góra Basin (western Poland). Geological Quarterly, 58 (1): 193-206, doi: 10.7306/gq.1140

\begin{abstract}
The Upper Rotliegend/Weissliegend sandstones in the Zielona Góra Basin are characterized by poorer reservoir properties than in the central part of the Polish Rotliegend Basin. However, there have been no detailed studies of the reasons for these differences. The main aim of this paper is to interpret the factors that played a major role in the distribution of reservoir properties in the Zielona Góra Basin. Analysis of variability in reservoir properties was performed using porosity-depth, permeability-depth, and permeability-porosity plots. The reservoir quality ratio (RQ), calculated by multiplying porosity and permeability values, was also introduced. The RQ ratio was found to be a useful tool to distinguish six types of reservoir rocks. Analyses of the variability of reservoir properties, coupled with microscopic observations, were discussed in relation to the sedimentary setting of each type of rock. These sedimentological and petrographical studies were intended to determine the variability of reservoir properties with respect to primary depositional or lithofacies effects and secondary diagenetic effects. The results indicate that cementation was a major factor controlling the distribution of reservoir properties, mainly by affecting the amounts of carbonate, sulphate, and illite. Compaction had only a minor influence on the reservoir properties studied here.
\end{abstract}

Key words: Rotliegend, Weissliegend, Fore-Sudetic Monocline, reservoir properties, reservoir quality ratio (RQ).

\section{INTRODUCTION}

The Upper Rotliegend has been the main target of natural gas exploration in western Poland for over fifty years (e.g., P. Karnkowski, 1999; Kwolek and Buniak, 2004; Wolnowski, 2004; Karnkowski, 2007; Kiersnowski et al., 2010a). Exploration has been focused on two regions: the Zielona Góra Basin, located south of Wolsztyn Ridge; and the Poznań Basin, north of Wolsztyn Ridge (Fig. 1). Currently, exploration is concentrated in the Poznań Basin, and the largest numbers of publications are from the Poznań Basin on the Rotliegend sedimentation (Karnkowski, 1987, 1994; Buniak, 1999; Buniak et al., 1999; Pokorski and Kiersnowski, 1999; Szwarc and Kiersnowski, 1999; Kiersnowski and Buniak, 2006; Kiersnowski et al., 2010b), on petrography (Rochewicz, 1980; Muszyński and Rydzewska, 1986; Gregosiewicz and Protas, 1997; Maliszewska and Kuberska, 2009), reservoir properties and their relationship to lithofacies (Such, 1996; Such et al., 2000; Buniak et al., 2009), and exploration of tight gas (Poprawa and Kiersnowski, 2008, 2010; Such et al., 2010). Several publications refer to the entire Polish Rotliegend Basin and the Zielona Góra Basin (Kiersnowski, 1997; Karnkowski, 1999; Jarzyna et

\footnotetext{
*E-mail: anna.poszytek@uw.edu.pl
}

Received: July 7, 2013; accepted: December 31, 2013; first published online: December 31, 2013 al., 2009; Papiernik et al., 2010); however, there are no detailed publications on the Zielona Góra Basin.

The Poznań Basin, located in the central part of the Polish Rotliegend Basin, is characterized by large thicknesses of the Upper Rotliegend, exceeding $2 \mathrm{~km}$, and a large contribution of aeolian sandstones in the section. In the Zielona Góra Basin, located in the marginal part of the basin, the thickness of the Rotliegend does not exceed $1000 \mathrm{~m}$, and the contribution of aeolianites in the section decreases towards the west in favor of fluvial sandstones.

Aeolian sandstones are the main reservoir rock for gas accumulation, but the reservoir properties in the two areas are considerably different (Poszytek, 2006; Jarzyna et al., 2009; Papiernik et al., 2010). The reservoir properties in the Poznań Basin are much better than in the Zielona Góra Basin. In the Poznań Basin, aeolian sandstones are characterized by very good reservoir properties (porosity $>20 \%$ and permeability $>1000 \mathrm{mD}$ ) and form a wide zone in the central part of the basin. Previous studies (Buniak et al., 2009) indicated that the decrease in the porosity and permeability values of aeolian sandstones to the south and north in the Poznań Basin is linked with the occurrence of fluvial deposits near Wolsztyn Ridge or with the larger subsidence of the Rotliegend, which is in turn connected with more intense compaction of aeolian sandstones.

In the Zielona Góra Basin, aeolian sandstones are less frequent in the succession, and their reservoir properties are often half those of the aeolian sandstones from the Poznań Basin. These sandstones are also characterized by a patchy lateral distribution of porosity and permeability values, which is re- 


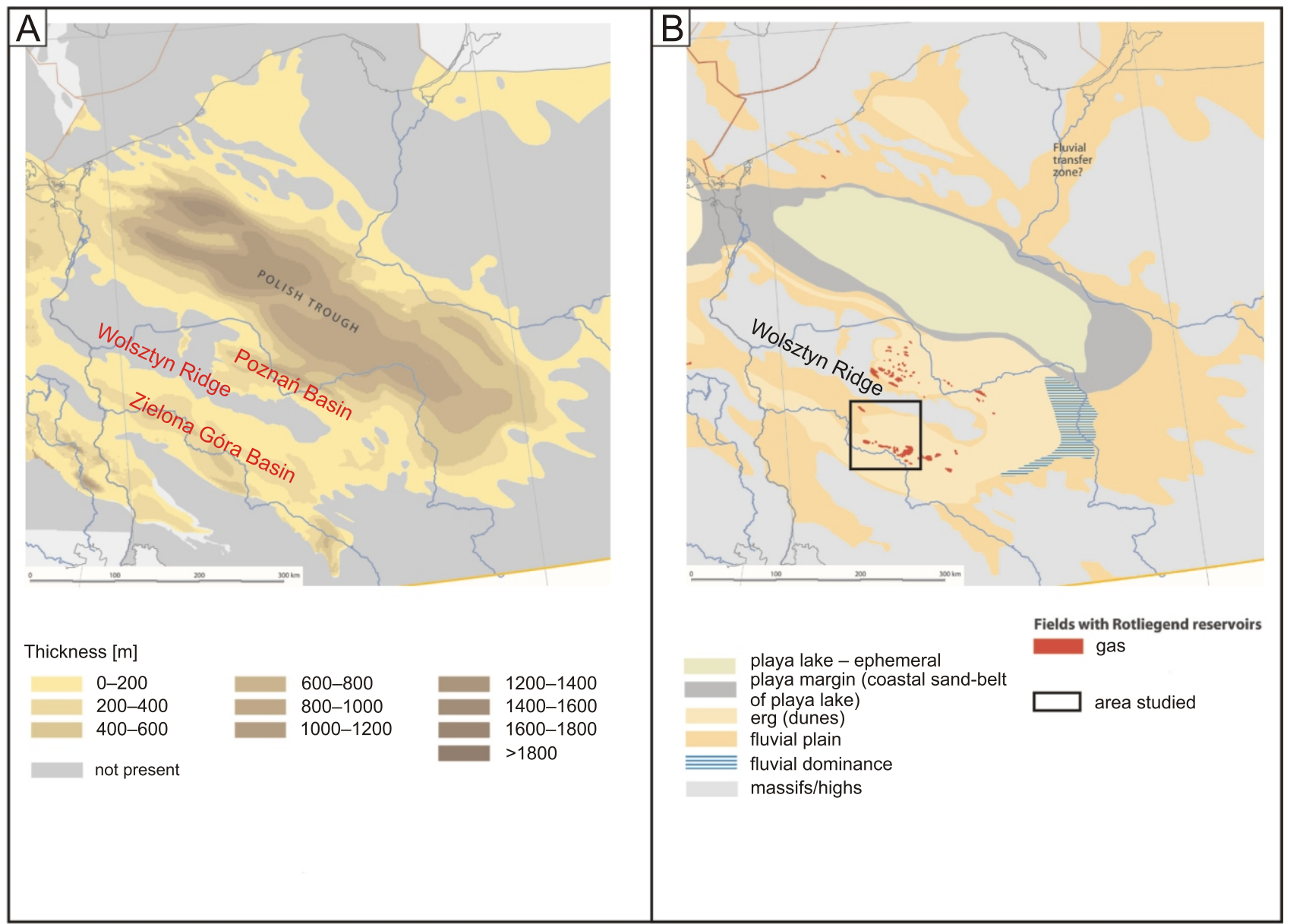

Fig. 1. Maps of the Polish Upper Rotliegend Basin

A - map of thickness, B - map of reservoir facies distribution (after Kiersnowski in Doornenbal and Stevenson, 2010)

flected in the close proximity of sections with good reservoir properties (porosity $>15 \%$, permeability $>100 \mathrm{mD}$ ) and poor reservoir properties (porosity $<5 \%$, permeability $<1 \mathrm{mD}$ ). In addition, in sandstones from the Zielona Góra Basin, high porosity is not necessarily collocated with high permeability, which results in difficulty in determining the lateral zones with the most positive reservoir properties.

Currently, the Zielona Góra Basin is considered a region of poor prospects for gas-field discoveries (Wolnowski, 2004). Among the reasons for this are the poor reservoir properties of the sandstone and the patchy lateral distribution of reservoir properties. However, there have been no complex studies that explained this variability in reservoir properties. It should be noted that over 100 boreholes were drilled in the Zielona Góra Basin from the 1970's to the 1990's, and huge amounts of geological information were collected: cores, thin sections, and laboratory measurements of porosity and permeability. Hence, the Zielona Góra Basin is still an excellent testing ground for analysis of reservoir properties on a regional scale. The main aim of this paper is to interpret the factors that played a major role in the distribution of reservoir properties in the Zielona Góra Ba$\sin$. The analyses described here are based on reinterpretation of archival data using modern knowledge.

\section{GEOLOGICAL SETTING}

The South Permian Basin system is located in Western and Central Europe, extending from Great Britain to Poland, and is one of the main regions for gas exploitation (Glennie, 1990; Ziegler, 1990; Karnkowski, 1999; Doornenbal and Stevenson, 2010). The gas plays consist of underlying source rock in Carboniferous sediments. The South Permian Basin system is divided into several sub-basins, of which one is the Polish Permian Basin, located in the eastern part of the overall basin system. The Polish Permian Basin was developed mostly by post-Variscan dextral trans-tension (Nikishin et al., 2002; Lamarche and Scheck-Wenderoth, 2005). The southern Permian (Rotliegend) Basin is filled with Lower Rotliegend (Autunian) sedimentary and volcanic rocks, and even in some places affiliated with the Rotliegend, Upper Carboniferous (Stefanian in age) red beds and volcanic rocks, as well as Upper Rotliegend clastic deposits. Sedimentation of the Upper Rotliegend rocks took place under arid and semi-arid continental conditions, and therefore the basin contains aeolian, fluvial, and playa deposits. Distribution of facies and their thickness in the Upper Rotliegend Basin was controlled by the Wolsztyn Ridge, a tec- 


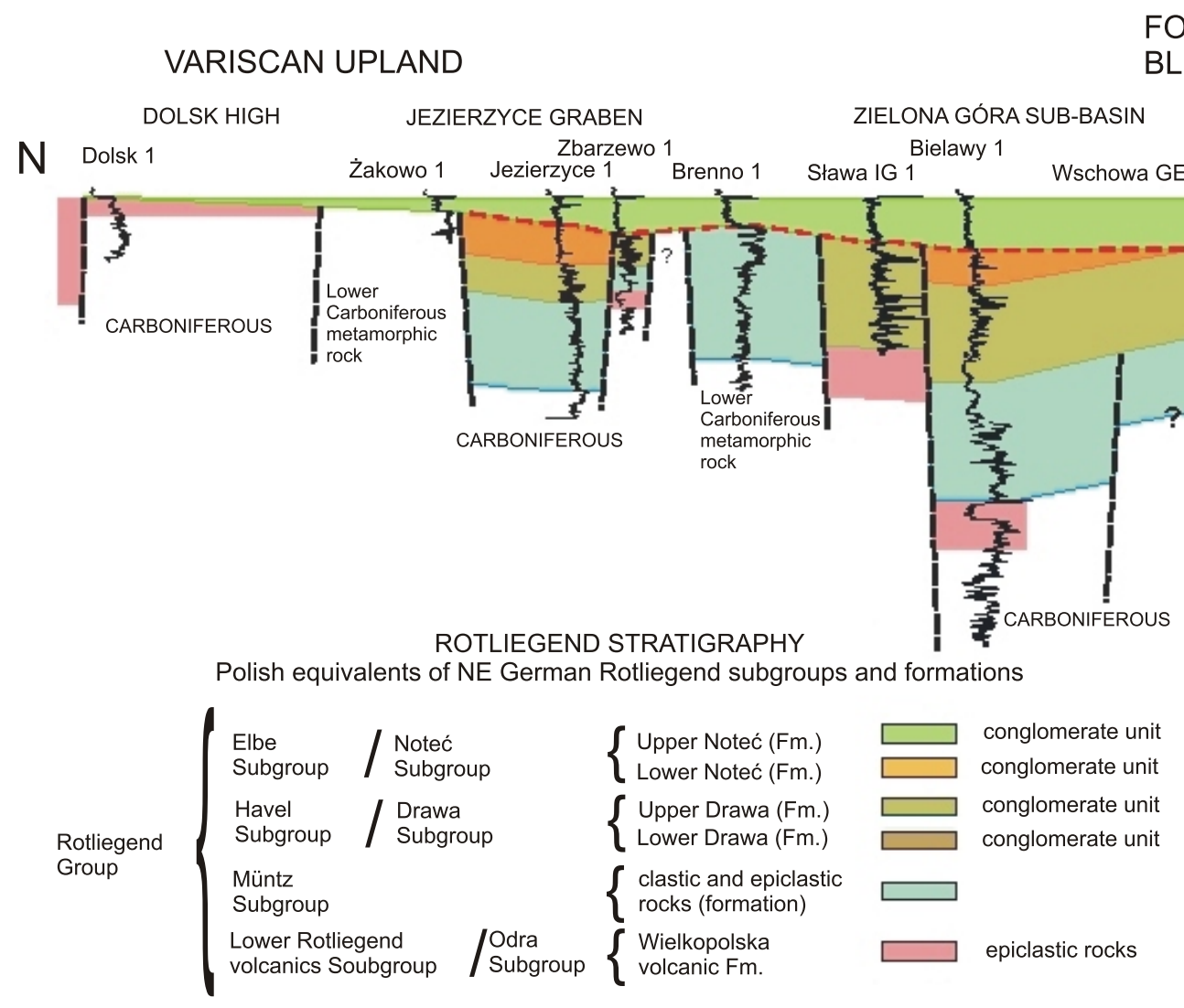

Fig. 2. Stratigraphic cross-section through the Polish part of the Rotliegend Southern Permian Basin (after Kiersnowski in Doornenbal and Stevenson, 2010)

tonic horst, which during the sedimentation of the Upper Rotliegend was the source area for fluvial sediments (Karnkowski, 1987, 1994; Weihe, 1997; Kiersnowski et al., 2010b). The Wolsztyn Ridge separated the southern part of the Rotliegend Basin into two parts: the northern Poznań Basin and the southern Zielona Góra Basin (Fig. 1). The Poznań Basin is located in the central part of the Polish Basin and is characterized by large thicknesses of the Upper Rotliegend, exceeding $2 \mathrm{~km}$, and a contribution of aeolian sandstones in the section. The Zielona Góra Basin is located on the SW margin of the Polish Basin; the thickness of the Rotliegend does not exceed $1000 \mathrm{~m}$, and the contribution of aeolianites in the section decreases towards the west (Fig. 1B). Continental Rotliegend sedimentation was terminated by the Zechstein transgression, which caused partial redeposition of poorly consolidated, porous, and permeable aeolian sands and loss of colour in the topmost part of the section. Bleached Rotliegend aeolian or fluvial sandstones and shallow-marine sandstones below the Kupferschiefer are assigned to the Weissliegend (Jerzykiewicz et al., 1976; Nemec and Porębski, 1977; Glennie et Buller, 1983; Karnkowski, 1986; Michalik, 2000, 2001; Kiersnowski, 2007). They are topped with the Zechstein Limestone deposits (Peryt et al., 2012) and then by the PZ1 evaporites (Wagner and Peryt, 1997; Kotarba et al., 2006).

Sandstones of the Zielona Góra Basin belong to the Drawa and Noteć formations (Fig. 2) and they are aeolian and fluvial origin. The Noteć Formation sandstones are covered by shallow-marine Weissliegend sandstones. Numerous conventional gas reservoirs have been recognized in Poland within the porous and permeable aeolian sandstones (Fig. 1B) sealed by
Zechstein evaporites and impermeable claystones, both in the Poznań and Zielona Góra basins (P. Karnkowski, 1999; Kwolek and Buniak, 2004; Wolnowski, 2004; Karnkowski, 2007; Kiersnowski et al., 2010a).

\section{METHODOLOGY}

The study was performed using data from boreholes drilled in the Zielona Góra Basin. Boreholes were selected from those having sufficient geological information: cores, thin sections, and laboratory measurements of effective porosity and horizontal permeability. In the first stage of the study, a macroscopic description of the cores was generated: the lithofacies were described, and the depositional environment of the rocks under study was interpreted. Next, a microscopic analysis of 31 thin sections from different depositional environments was performed. The mineral composition of the grain framework, degree of grain sorting, intergranular contacts, and cements, as well as the character and value of porosity, were described. These sedimentological and petrographical studies were intended to determine the variability of reservoir properties with respect to primary depositional or lithofacies effects and secondary diagenetic effects. Then an analysis of 1230 porosity and permeability measurements was carried out. Measurements of porosity and permeability were collected from sandstones of different origins, lithologies, and depths of occurrence. These investigations aimed to establish relationships between porosity and depth, permeability and depth, and permeability and porosity. The reservoir quality ratio $(R Q)$, calculated 
A

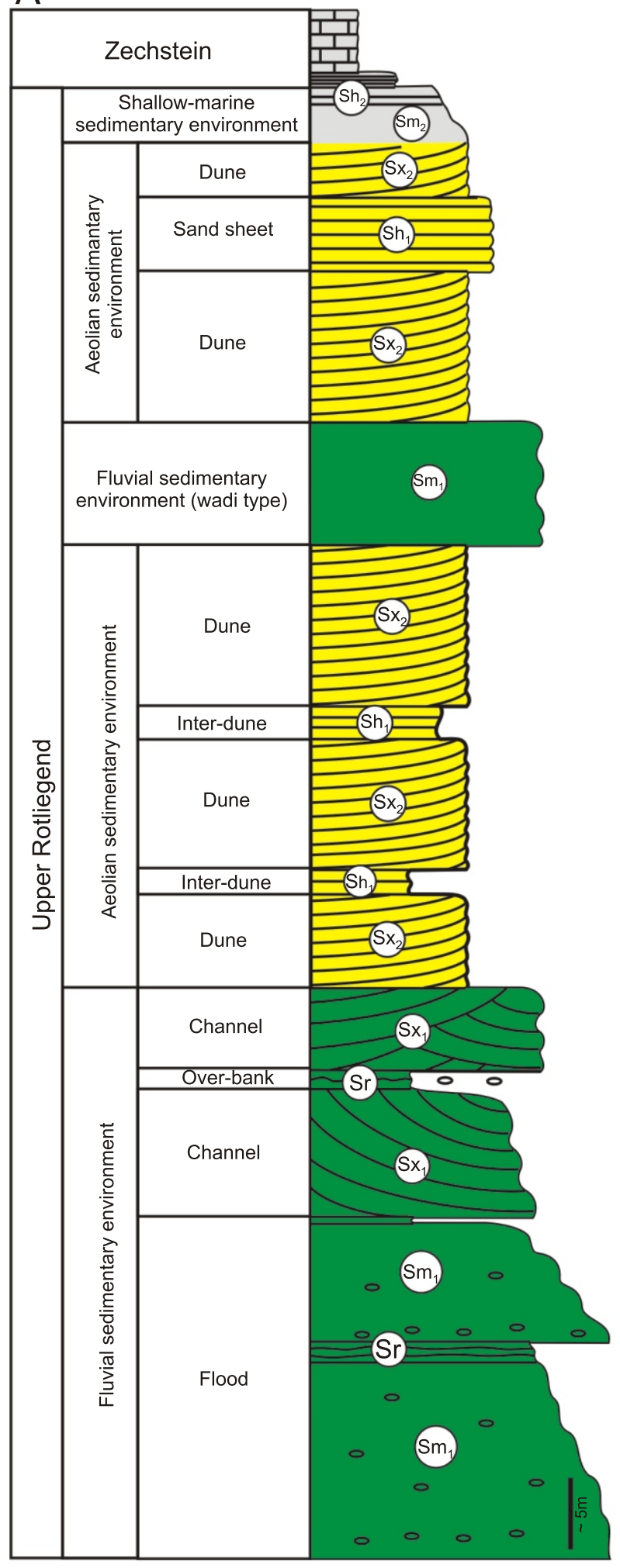

B

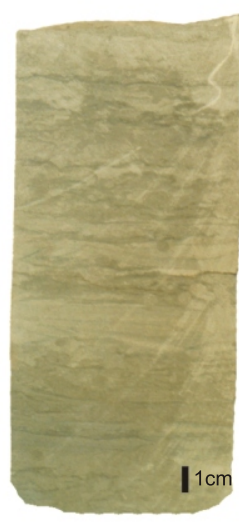

Lithofacies $\mathrm{Sm}_{2}$

\section{C}
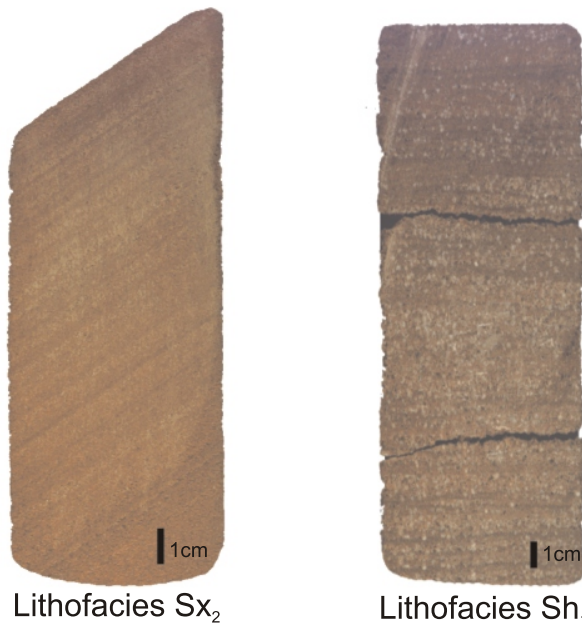

Lithofacies $\mathrm{Sh}_{1}$

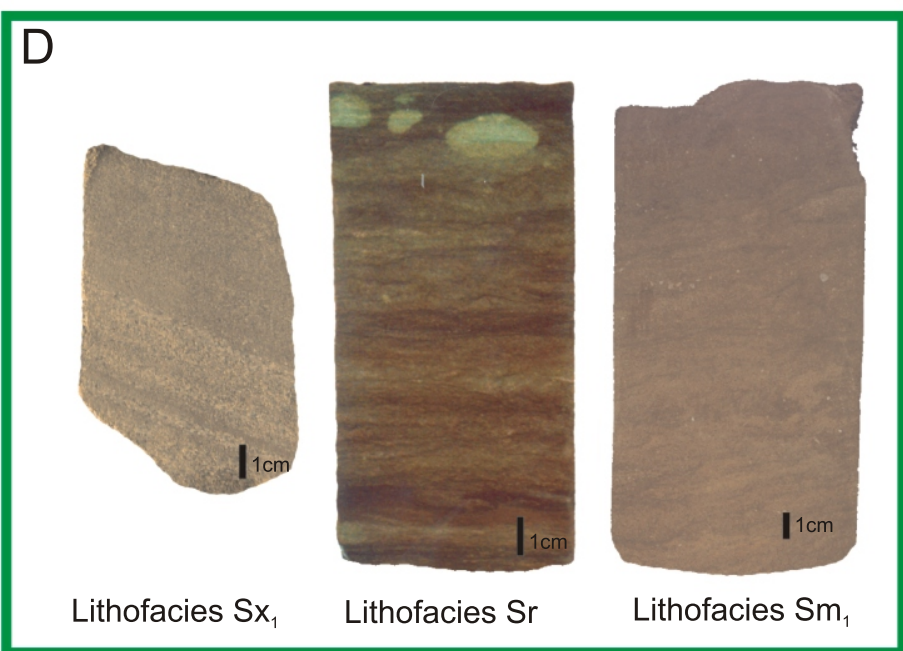

Fig. 3. Lithofacies of the Upper Rotliegend sandstones in the Zielona Góra Basin

A - schematic profile; B - shallow-marine sandstones; C - aeolian sandstones; D - fluvial sandstones; Sm - massive sandstones, $\mathrm{Sh}$ - sandstones with horizontal bedding, $\mathrm{Sx}$ - sandstones with cross-bedding, $\mathrm{Sr}$ - sandstones with ripple bedding; for lithofacies code see Table 1 
Lithofacies classifications and descriptions (modified from Miall, 1978)

\begin{tabular}{|c|c|c|c|}
\hline $\begin{array}{l}\text { Lithofacies } \\
\text { code }\end{array}$ & Description & Interpreted environment & \\
\hline$S x_{1}$ & $\begin{array}{l}\text { cross-bedded sandstones, medium- to coarse-grained, } \\
\text { poor sorted, thickness from } 2 \text { up to } 10 \mathrm{~m}\end{array}$ & channel & \multirow{3}{*}{ fluvial } \\
\hline $\mathrm{Sr}$ & $\begin{array}{l}\text { ripple-laminated silty sandstones, fine- to } \\
\text { coarse-grained, poorly sorted, thickness to few metres }\end{array}$ & over-bank & \\
\hline $\mathrm{Sm}_{1}$ & $\begin{array}{l}\text { massive sandstones, medium- to coarse-grained, poor } \\
\text { sorted, with fine pebbles, thickness from } 0.5 \text { up to } 15 \mathrm{~m}\end{array}$ & flood & \\
\hline $\mathrm{Sx}_{2}$ & $\begin{array}{l}\text { high-scale cross-bedded sandstones, fine- to me- } \\
\text { dium-grained, well-sorted, thickness up to } 30 \mathrm{~m}\end{array}$ & dune & \multirow{2}{*}{ aeolian } \\
\hline $\mathrm{Sh}_{1}$ & $\begin{array}{l}\text { plane-bedded sandstones, medium- to coarse-grained, } \\
\text { well-sorted, thickness from } 0.5 \text { up to } 10 \mathrm{~m}\end{array}$ & interdune or sand sheet & \\
\hline $\mathrm{Sm}_{2}$ & $\begin{array}{l}\text { massive sandstones often with bioturbation and rare fos- } \\
\text { sils, fine- to medium-grained, well-sorted, cemented by } \\
\text { calcite, thickness from } 2 \text { up to } 15 \mathrm{~m}\end{array}$ & $\begin{array}{l}\text { redeposition of unconsolidated aeolian sands } \\
\text { during marine transgression }\end{array}$ & \multirow{2}{*}{$\begin{array}{l}\text { shallow- } \\
\text { marine }\end{array}$} \\
\hline $\mathrm{Sh}_{2}$ & $\begin{array}{c}\text { plane-bedded sandstones, fine- to medium-grained, } \\
\text { laminated by thin clay layers, cemented by calcite, } \\
\text { thickness from } 0.5 \text { to } 2 \mathrm{~m}\end{array}$ & shallow-marine & \\
\hline
\end{tabular}

by multiplying porosity and permeability values, was also introduced. The $R Q$ ratio enables classification of reservoir rocks. Until now, no analysis of reservoir properties had been performed using the $R Q$ ratio.

\section{SEDIMENTOLOGICAL AND PETROGRAPHIC CHARACTERISTICS}

Sandstones were formed in three types of sedimentary settings: fluvial, aeolian and shallow-marine environments were noted in the study area (Fig. 3). Fluvial rocks occur in the lower parts of the profiles throughout the study area. They are developed as sandstones and conglomerates (Fig. 3). In addition, fluvial sandstones dominate profiles in the western part of the area and near Wolsztyn Ridge (up to several hundred metres thick). Aeolian sandstones occur in the upper parts of the profiles and dominate in the eastern and southern parts of the area. Their thickness increases towards the east (up to several hundred metres). In the central part of the basin, a zone occurs with lateral alternation of aeolian and fluvial sandstones. These aeolian and fluvial sandstones are covered with Weissliegend sandstone (to several metres). Depending on facies and petrography, the sandstones can be characterized by their particular reservoir properties. The facies classification was based on a modified version of the code proposed by Miall (1978; Table 1).

Fluvial sandstones include sandstones formed in the channel and interchannel parts of the flood plain (Fig. 3 and Table 1). Over-bank facies and those formed during floods are characterized by poor sorting and massive structure of the sandstone-conglomeratic facies $\left(\mathrm{Sm}_{1}\right)$ and a rippled structure in the case of sandstone-siltstone facies (Sr). Channel deposits are characterized by better sorting than over-bank facies and a distinct horizontal or cross-stratification $\left(\mathrm{Sx}_{1}\right)$. The thickness of the fluvial deposits reaches $100 \mathrm{~m}$, and they dominate in the lower part of the analyzed sections. Fluvial facies have also been noted as several-meter-thick intercalations within aeolian deposits in the upper parts of the sections (Fig. 3). In this case, they are represented by poorly sorted massive sandstones $\left(\mathrm{Sm}_{1}\right)$ with a distinct erosional lower boundary. These deposits reflect the development of a wadi-type river network within the dune field.

According to the classification of Pettijohn et al. (1972), the fluvial lithofacies include lithic and sublithic arenites (Fig. 4).
The grains are characterized by poor sorting. These lithofacies are characterized by the presence of much larger quartz grains in comparison to rock clasts and feldspars (Fig. 5B), which is linked to the better resistance of quartz grains to disintegration during fluvial transport. The rock clasts include mainly volcanic rocks from erosion of the Wolsztyn Ridge. The grains are densely packed, and the intergranular contacts are point or planar, indicating physical compaction. The framework often contains matrix and carbonate cement (Fig. 6C), which fills it partly or completely, resulting in a decrease in effective porosity.

Aeolian sandstones include well-sorted and distinctly bedded sandstones up to several hundred metres thick (Fig. 3 and Table 1). They contain a several-meter-thick packet of high-angle cross-stratified sandstones $\left(\mathrm{Sx}_{2}\right)$, evidencing a dune setting. Dune sandstones also include massive sandstones and silty

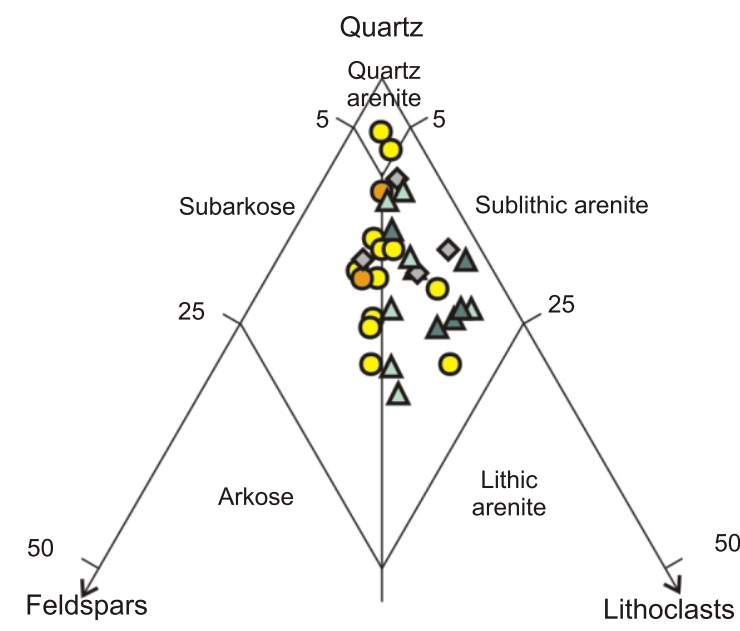

Sedimentary environment of sandstones:

$\diamond$ shallow-marine

O dune

O inter-dune or sand sheet

$\Delta$ channel

$\Delta$ ober-bank

Fig. 4. The mineral composition of skeletal grains of sandstones in the classification diagram QFL of Pettijohn et al. (1972) 

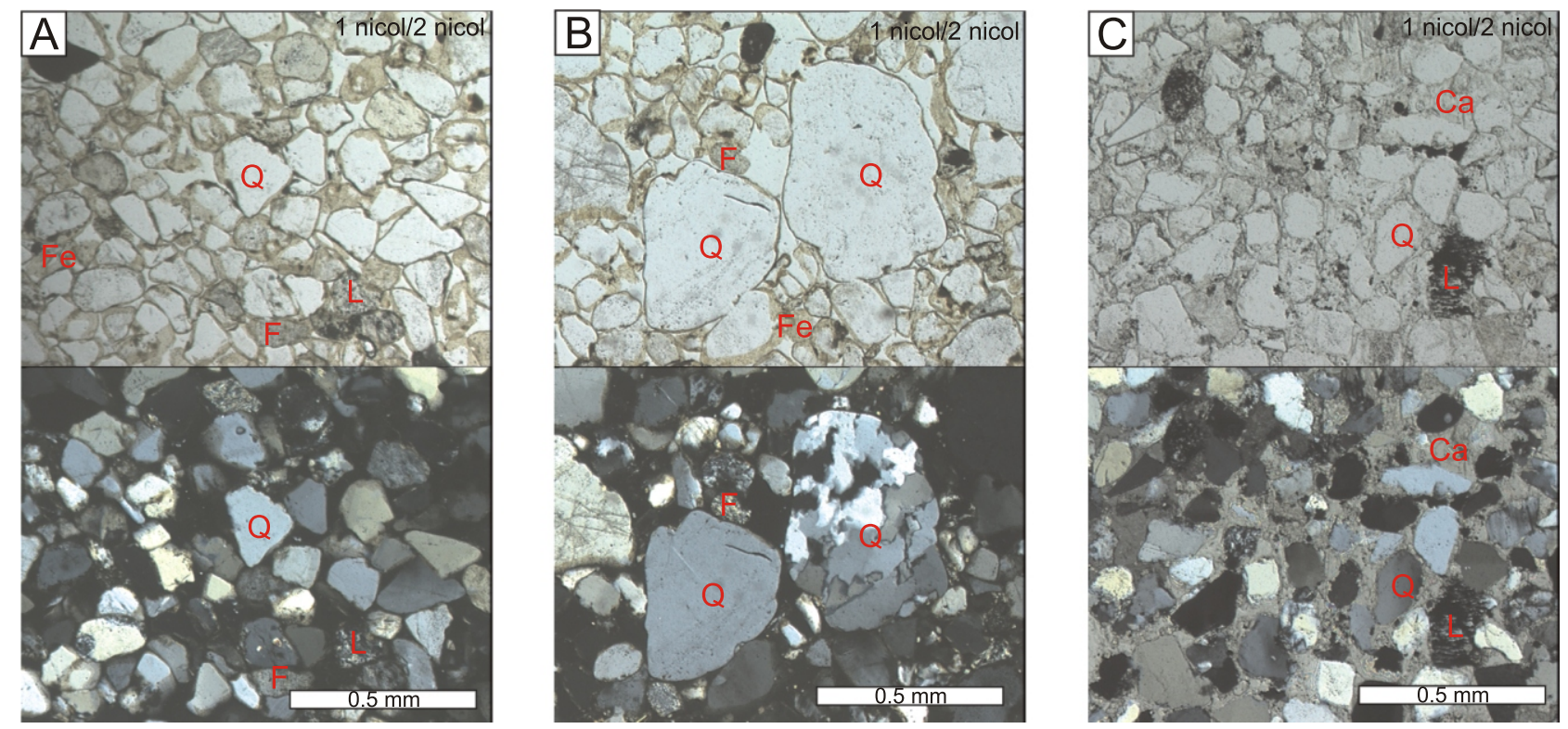

Fig. 5. Microscopic images of sandstones

A - aeolian, B - fluvial, C - shallow-marine; Ca - carbonate cements, F - feldspars, Fe - haematite coatings, L - lithoclasts, Q - quartz
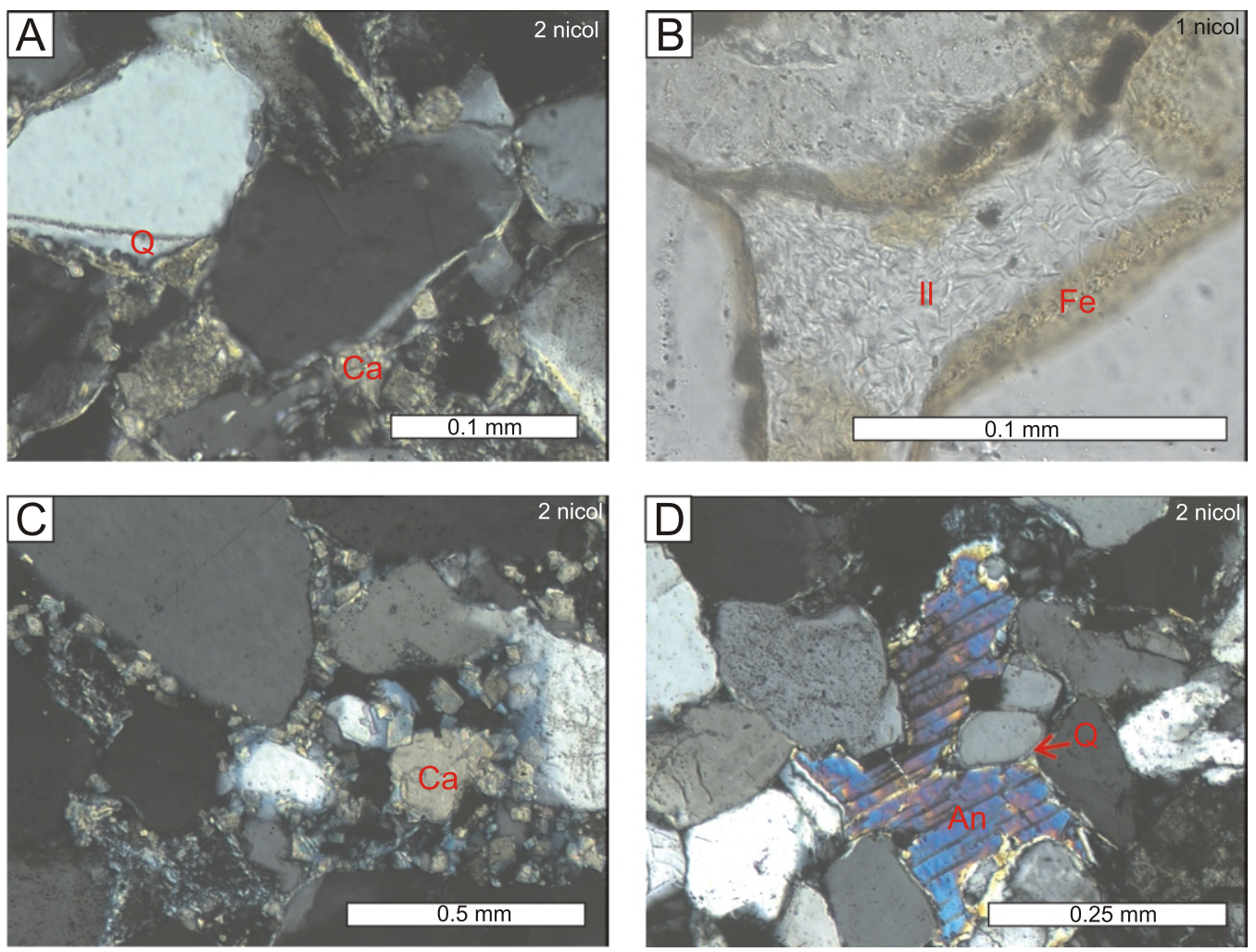

Fig. 6. Microscopic images of cement filling intergranular space

A - quartz coatings and carbonate cements; B - ferruginous coatings and illite cements; C - carbonate cements; D - quartz coatings and anhydryte cements; $\mathrm{An}$ - anhydrite, $\mathrm{Ca}$ - carbonates,

$\mathrm{Fe}$ - haematite coatings, II - illite, Q - quartz coatings 
sandstones with horizontal bedding $\left(\mathrm{Sh}_{1}\right)$, from $0.5 \mathrm{~m}$ to several metres thick, which were formed in depressions between the dunes. Horizontally bedded sandstones with thicknesses exceeding several metres have been interpreted as sandstones formed within sand sheets.

According to the classification of Pettijohn et al. (1972), aeolian sandstones include quartz and sublithic and subarkosic arenites (Fig. 4). The presence of sublithic and subarkosic arenites in aeolian facies may be caused by interfingering of aeolian and fluvial environments, which could have caused the redeposition of non-consolidated particles of fluvial origin (feldspars and rock fragments) into aeolian sands during arid periods (Kiersnowski, 1997; Sweet, 1999). Aeolian lithofacies are characterized by the best grain sorting and the highest porosity among all Rotliegend sandstone lithofacies (Fig. 5A). High porosity is accompanied by low cement content, mainly in the form of clay-haematite grain coatings and rare quartz coatings on the quartz grains (Fig. 6A, B). However, a large part of the aeolian sandstones is characterized by intense cementation by carbonate and sulphate minerals as well as illite (meshwork illite; Gaupp, 1997), which considerably decreases primary porosity and permeability (Fig. 6B). Based on studies in the Zielona Góra Basin (Michalik, 1996) and in the Poznań Basin (Maliszewska, 1997; Maliszewska and Kuberska, 2009), it is assumed that illite crystallisation took place in the Jurassic, probably during hydrothermal events related to tectonic activity (Maliszewska and Kuberska, 2009). Isotopic studies from Germany (Gaupp et al., 1993; Zwingmann et al., 1998), the Netherlands (Gaupp and Okkerman, 2011), and the North Sea (Gluyas and Leonard, 1995) show results similar to those from Poland (Maliszewska and Kuberska, 2009). This indicates that the illite cementation process was a regional hydrothermal phenomenon. Therefore, at least until that time, the deposits were characterized by high permeability. In turn, the carbonate and sulphate cements could be early as well as late diagenetic (Kuberska, 2004). However, the late diagenetic carbonate and sulphate cements occurring in the deeper parts of the sections did not restrict porosity to the same extent as the early diagenetic cements occurring in the topmost parts of the sections (Fig. 6D).

Dissolution of unstable framework grains (feldspars and volcanic rock fragments) was found in the rocks under study. This phenomenon, however, is not common. In place of the dissolved particles, low secondary porosity occurs within the clay residue. However, secondary porosity is low and does not impact overall porosity.

Shallow-marine sandstones include massive and horizontally bedded sandstones, often with bioturbations and siltstone intercalations, which occur in the topmost parts of the sections (Fig. 3 and Table 1). Massive sandstones $\left(\mathrm{Sm}_{2}\right)$ were formed due to redeposition of non-consolidated, primarily aeolian sandstones during the initial phases of the Zechstein transgression. These massive, transitional sandstones pass gradually into typical shallow-marine sandstones: laminated $\left(\mathrm{Sh}_{2}\right)$ and massive with bioturbations $\left(\mathrm{Sm}_{2}\right)$. Microscopic studies have shown that according to the classification of Pettijohn et al. (1972), the sandstones represent quartz and sublithic and subarkosic arenites, similarly to the aeolian deposits (Fig. 4). They are characterized by a high content of carbonates and sulphate cements, which restrict the high primary porosity (Fig. 5C). Sandstones with a large content of carbonates and sulphate cements are characterized by the prevalence of point types of intergranular contacts, which suggests an insignificant contribution from compaction and the early diagenetic character of the cement, which actually prevented compaction. In sandstones with low carbonate and sulphate cement contents, the intergranular contacts are point and planar, indicating physical compaction during burial of these rocks.

\section{VARIABILITY OF RESERVOIR PROPERTIES}

The variability of porosity and permeability has been described by the relationships of porosity and permeability to depth and the relationship of permeability to porosity. The deterioration of the reservoir properties of clastic rocks with depth is caused by sediment compaction and reduction of pore space, which restricts porosity and decreases permeability (Tiab and Donaldson, 2004). However, the magnitude of compaction in sandstone depends not only on the burial history, but also on the mineral composition of the grain framework, its sorting and rounding, and the presence of matrix and early diagenetic cements (Beard and Weyl, 1973; Houseknecht, 1987; Bjørlykke et al., 1989; Hogg et al., 1996; Amthor and Okkerman, 1998). The influence of the remaining factors is very clearly visible in the Rotliegend sandstones from the Zielona Góra Basin, where there is no direct relationship between porosity and permeability reduction and depth within the described sedimentary settings (Fig. 7).

No distinct trends of porosity and permeability decrease with depth were found within the fluvial deposits (Fig. 7). Most probably, local factors influencing the lithology of these deposits, such as sorting or the presence of matrix, exerted more control over the reservoir properties of fluvial sandstones than did burial processes.

In aeolian sandstones, porosity and permeability change abruptly with depth, a phenomenon which is particularly distinct in dune deposits (Fig. 7). This is probably linked with local variability in sample lithology (e.g., content of illite cements in the pore space).

The shallow-marine Weissliegend sandstones generally show a decrease of porosity and permeability with depth. However, the same sandstones are characterized by higher reservoir properties than the samples collected as described above (Fig. 7). The maximum values of porosity and permeability are found in sandstones that did not undergo full cementation by carbonate and sulphate minerals, which made their porosity/permeability and hence reservoir quality similar to those of aeolian sandstones. The lack of early diagenetic cement resulted in a susceptibility to compaction that restricted primary porosity.

The next stage of the study was to analyse the charts showing the relationships of permeability to porosity (Fig. 8), which made it possible to trace the relationships of porosity and permeability changes and to discuss which factors besides compaction could have caused deviations from the general trend (Either and King, 1991; Cade et al., 1994; Evans et al., 1997).

In the case of aeolian deposits, the dune sandstones, which are potentially the most favorable reservoir rocks with the best qualities, do not form isolated fields, but are mixed with sandstones from the interdune areas and sand sheets (Fig. 8). The reservoir properties of aeolian sandstones from the Zielona Góra Basin are highly variable. Sandstones with porosity below $15 \%$ and permeability of $1 \mathrm{mD}$ (Fig. 8 A, type A) occur in the topmost parts of the sections, where during the Zechstein transgression, infiltration and cementation of the pore space by carbonate and sulphate minerals took place. In contrast, aeolian sandstones with porosity $>15 \%$ and permeability $<1 \mathrm{mD}$ (Fig. 8A, type B) represent sandstones in which the pore space is completely filled with meshwork illite or silty sandstones from the interdune areas. Most measurements in the aeolian sand- 

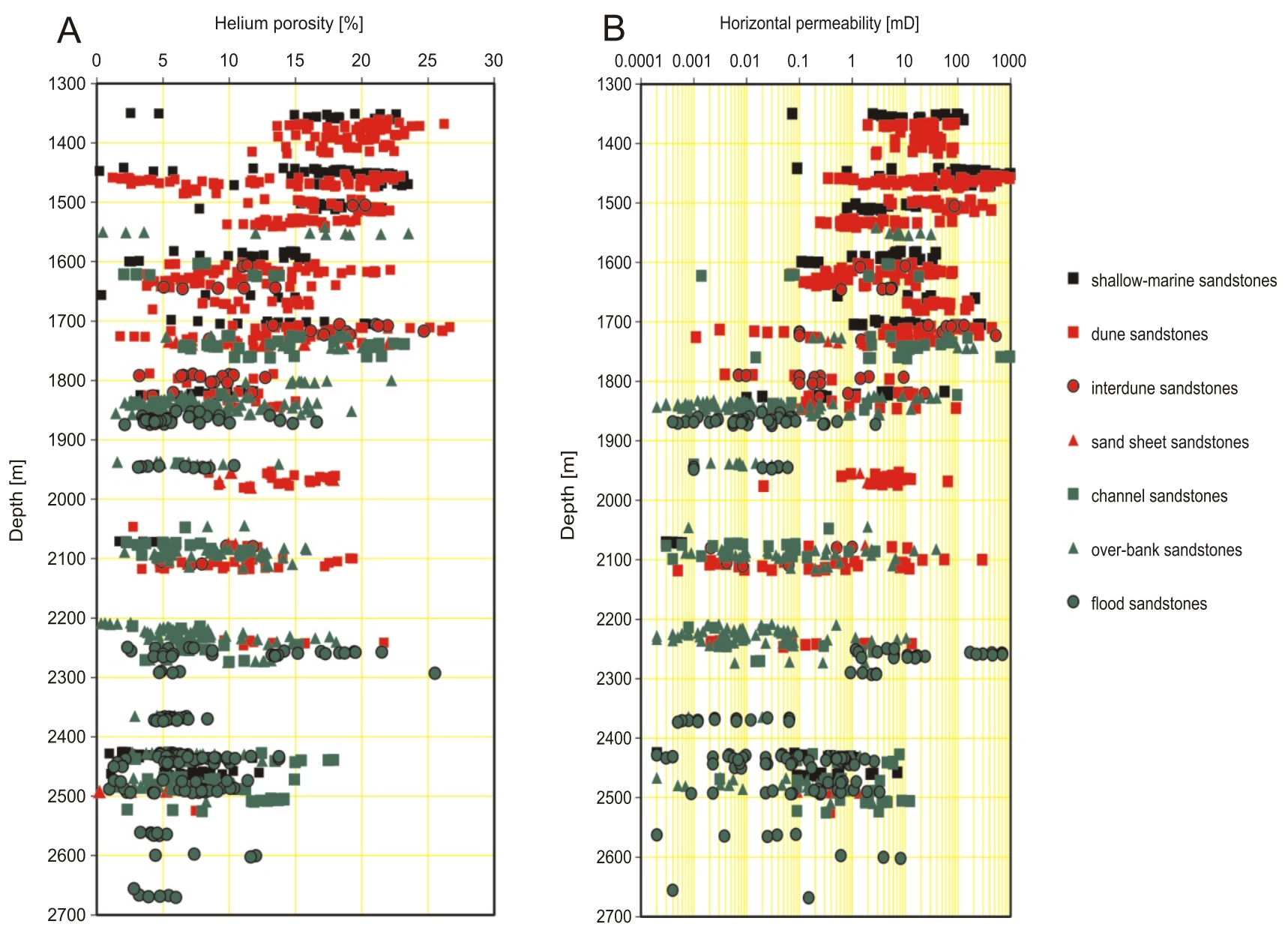

Fig. 7. Graphs showing the relationship of porosity and permeability with depth for the Rotliegend and Weissliegend sandstones from the Zielona Góra Basin

A - relationship of porosity with depth; $\mathbf{B}$ - relationship of permeability with depth

stones point to a permeability from $0.1 \mathrm{mD}$ to almost $100 \mathrm{mD}$ at a very wide range of porosities (from 3 to $20 \%$; Fig. 8 A, type C). This phenomenon can be caused by a number of factors, which often act independently, such as sorting, compaction, and type of cements and how they fill the pore space (Either and King, 1991; Cade et al., 1994; Evans et al., 1997). The last group of dune sandstones is characterized by very good reservoir properties (porosity $>15 \%$, permeability $>100 \mathrm{mD}$; Fig. $8 \mathrm{~A}$, type D) and include well-sorted sandstones with a small contribution of cement in the pore space.

Fluvial sandstones are characterized by less favorable reservoir properties than aeolian sandstones (Fig. 8). Sandstones with very poor reservoir properties (porosity $<10 \%$ and permeability $<0.01 \mathrm{mD}-$ Fig. 8B, type A) are dominant. They are represented by poorly sorted sandstones, often conglomeratic, with a high content of matrix in the pore space. The next group of fluvial sandstones is characterized by permeability within the $0.0110 \mathrm{mD}$ range and a very wide dispersion of porosities, 2-20\% (Fig. 8B, type B). This can be caused by a number of factors, such as grain sorting, matrix content, and compaction intensity (Either and King, 1991; Cade et al., 1994; Evans et al., 1997). High reservoir properties with porosity $>15 \%$ and permeability $>10 \mathrm{mD}$ (Fig. 8B, type C) occur in well-sorted sandstones with a small contribution of matrix in the pore space, which were derived from the redeposition of aeolian sandstones during the development of wadis in the dune fields.
Two groups of rocks can be distinguished in the shallow-marine sandstones. The first has very poor reservoir properties (permeability $<1 \mathrm{mD}$ and porosity of only a few percent; Fig. 8C, type A). The second group exhibits a distinct trend in the permeability-to-porosity relationship (Fig. 8C, type B). The first group includes clayey sandstones formed under shallow-marine conditions, in which compaction and cementation have significantly restricted the reservoir properties. The second group includes sandstones formed due to redeposition of dune sands. Their reservoir properties have been influenced by cementation by carbonate and sulphate minerals. Therefore, depending on the contribution of cement in the pore space, their porosity and permeability values change proportionally: porosity within $218 \%$ and permeability within $0.11000 \mathrm{mD}$. Note that the highest porosity values in the shallow-marine deposits are lower than the highest porosity values in the aeolian sandstones. The reason for this lies in partial cementation, compaction, or both, in which lack of cement can cause reduction of porosity. This fact is also evidenced by charts showing the relationships of porosity and permeability to depth.

These characteristics indicate that the Rotliegend and Weissliegend sandstones from the Zielona Góra Basin exhibit wide variability in reservoir properties which is not correlated with sedimentary conditions. There is also no correlation between permeability and porosity, which causes difficulty in determining the zones with the highest reservoir quality. There- 
fore, an attempt was made to classify the reservoir properties and to describe the most important factors influencing the presence of zones with highest and lowest reservoir quality.

\section{CLASSIFICATION OF RESERVOIR PROPERTIES}

In practice, a commonly used coefficient is the FZI (Flow Zone Indicator; Corbett and Potter, 2004; Bała and Jarzyna, 2004) that uses the Kozeny-Carman formula (Tiab and Donaldson, 2004) based on the relationship of permeability to porosity. This indicator makes it possible to recognize rocks with similarly developed pore space, as determined by their origin and similar diagenetic processes. However, in the case of the Rotliegend and Weissliegend sandstones from the Zielona Góra Basin, this task is very difficult due to the complex origin (aeolian, fluvial, and shallow-marine sandstones) and diagenesis of the rocks under study (compaction, cementation by ferritic illite, carbonate, and sulphate minerals, where each of these processes took place at a different time and with different intensity). Therefore, to classify the reservoir rocks, the reservoir quality ratio $(R Q)$ has been introduced here, which is calculated by multiplying the measured porosity in a given sample [\%] by the permeability [mD]:

\section{$\mathrm{RQ}$ ratio $=$ porosity $[\%] \times$ permeability $[\mathrm{mD}]$}

The $R Q$ ratio does not characterize any physical property of the rock, but is the value of its reservoir quality and is used to characterize, not the pore space, but the reservoir properties, i.e., the capability of the deposits under study to collect and conduct fluids.

Following the classification of Levorsen (1967), who subdivided reservoir rocks using porosity and permeability values, six types of reservoir rocks based on the $R Q$ ratio have been distinguished in this research (Fig. 9). The boundaries between the rock types are oblique to the general trend of the permeability-porosity relationship and change logarithmically, similarly to the values of the permeability coefficient, which largely determines the $R Q$ ratio:

1. Type I: RQ (porosity × permeability) 1 - "tight" rocks;

2. Type II: RQ (1-10) - rocks with very low reservoir quality;

3. Type III: RQ (10-100) - rocks with low reservoir quality;

4. Type IV: RQ (100-1000) - rocks with medium reservoir quality;

5. Type V: RQ $(1000-10,000)$ - rocks with high reservoir quality;

6. Type $\mathrm{VI}: \mathrm{RQ}>10,000$ - rocks with very high reservoir quality.

The distribution of the $R Q$ ratio is presented in the chart showing the relationship between porosity and permeability for all Rotliegend and Weissliegend sandstones from the Zielona Góra Basin. It makes it possible to distinguish rocks with high and very high reservoir quality - classes 5 and 6 (rocks with porosity above $15 \%$ and permeability above $100 \mathrm{mD}$ ), linked with

Fig. 8. Graphs showing the relationship of permeability to porosity with regard to particular sedimentary conditions

A - relationship of permeability to porosity for aeolian sandstones;

B - relationship of permeability to porosity for fluvial sandstones; C - relationship of permeability to porosity for shallow-marine sandstones

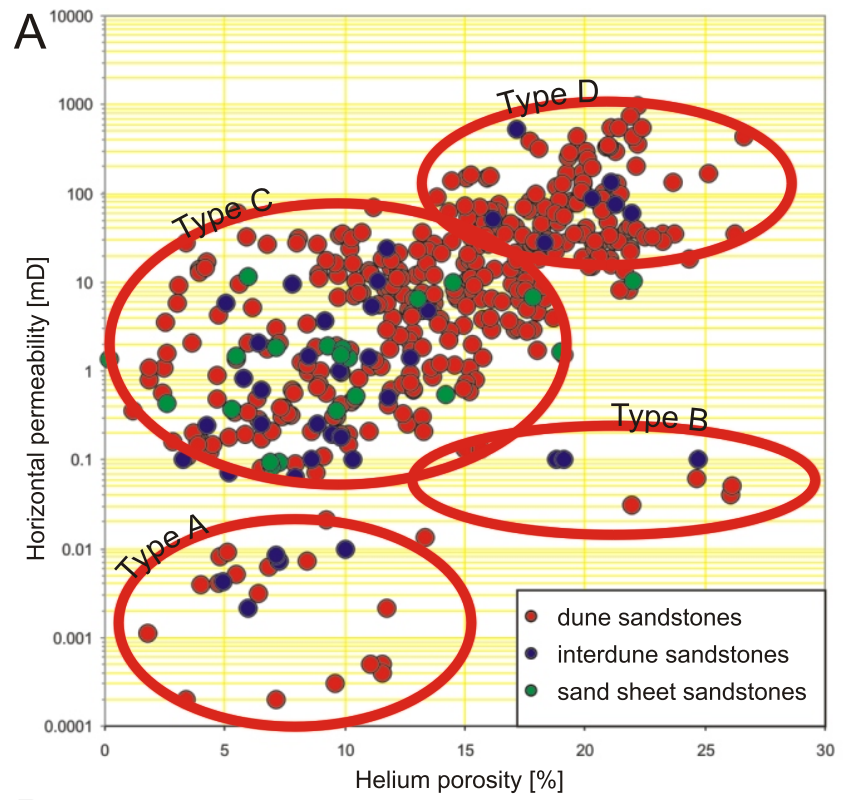

$B$
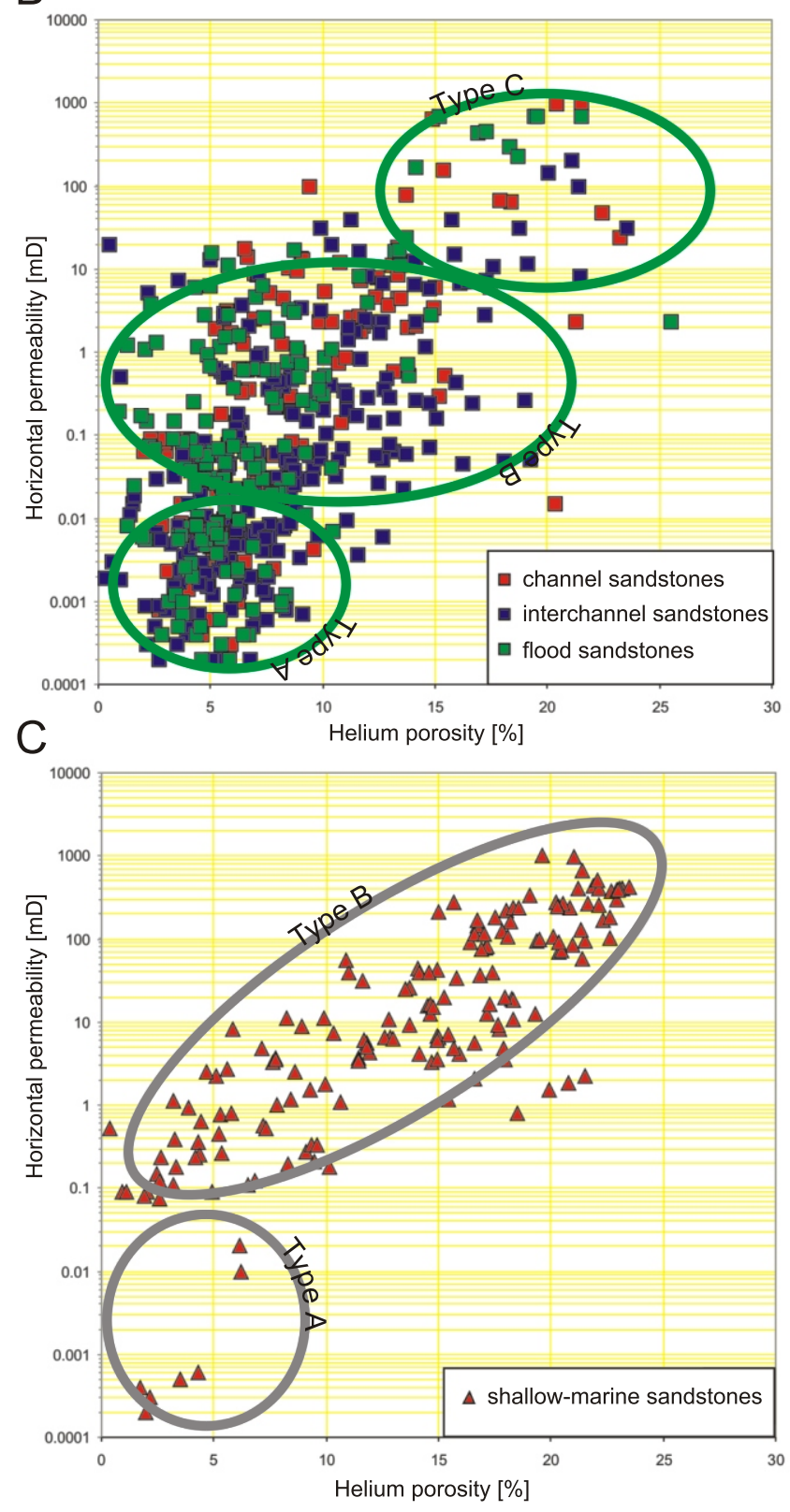


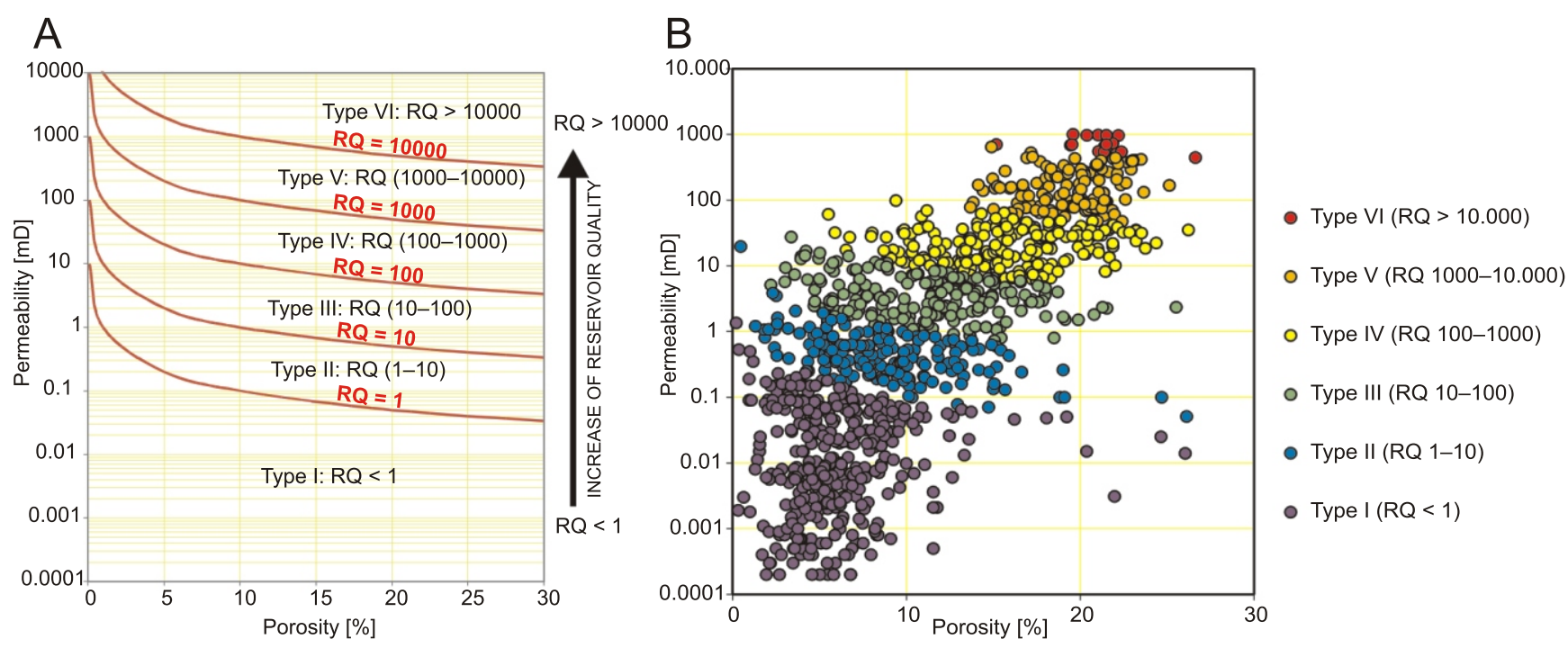

Fig. 9. Chart showing the relationship between permeability and porosity with: A - borders of classes of reservoir rocks distinguished by the $R Q$ ratio; $B$ - sample divided into classes based on reservoir quality ratio (RQ)

aeolian sedimentation or redeposition of dune sands, characterized by good sorting and low cement content in the pore space. On the opposite side are rocks of class 1 - "tight" rocks, for which permeability falls below $0.11 \mathrm{mD}$ and porosity is slightly above $10 \%$. These are sandstones with a high content of cement, matrix, or both in the pore space, which significantly restricts permeability. In the remaining classes (2, 3 and 4$)$, porosity values are widely dispersed. This phenomenon is caused by a number of factors which depend on the origin of rocks and the diagenetic processes to which they have been subjected. This is reflected as grain sorting, matrix and cement content, and compaction intensity (Either and King, 1991; Cade et al., 1994; Evans et al., 1997). The various factors affecting porosity and permeability are difficult to separate from each other and represent the dominant factors affecting reservoir properties. However, it can be assumed that a porosity of less than $10 \%$ and a permeability $>10 \mathrm{mD}$ is related to an increase in grain size. A porosity $>10 \%$ and a permeability $<10 \mathrm{mD}$ can be associated with the occurrence of microporosity associated with the presence of illite in the intergranular pore space.

The variability of the $R Q$ ratio has also been shown on the map with the mean value of the $R Q$ ratio in the topmost $(50 \mathrm{~m})$ interval of the Rotliegend and Weissliegend (Fig. 10). This interval contains most of the gas reservoirs in the area, and therefore it is usually almost fully cored and very well-recognized. The map was compiled based on cores with sedimentological and petrographic analyses as well as data from other boreholes in the study area available in the PGNiG archives. The mean value of the $R Q$ ratio was determined for each borehole for the topmost $50 \mathrm{~m}$ of the Rotliegend interval, and a map of its distribution was compiled.

The map shows that the central part of the Zielona Góra Basin contains rocks of medium reservoir quality linked with aeolian rocks, which to the north, south, and west pass into rocks of very low reservoir quality and into "tight" rocks. To the north and west, reduction of reservoir properties is linked to the appearance of fluvial sandstones with high matrix content in the pore space. The decrease of reservoir properties to the south is linked to intense cementation of aeolian sandstones with mesh- work illite. Within the zone with medium reservoir properties (prevalence of aeolian facies) occur isolated, small areas with high reservoir quality which often lie adjacent to areas with low reservoir properties. The reason for this may be the presence of numerous synsedimentary faults in the Rotliegend deposits (Fig. 10), which could provide a path for fluid migration and cementation of aeolian sandstones. However, there is no clear evidence for a link between the structural position of sandstones and the $R Q$ ratio (Fig. 10). So far, detailed study of this problem has not been carried out in Poland.

To explain this patchy distribution of reservoir quality, the $R Q$ ratio was interpreted with regard to sedimentary conditions and microscopic observations. The triangle graph representing the percentage contribution of particular sedimentary conditions in the sections under study (Fig. 11) indicates that the value of the $R Q$ ratio is not strictly linked with rock origin. However, analysis of the $R Q$ ratio in relation to microscopic observations gave a clearer correlation. The chart showing the percentage content of clay (matrix and/or meshwork illite), chemical cements (carbonates and sulphates), and pores not filled with cement indicates that cementation was the main factor determining reservoir properties (Fig. 12). Early diagenetic cementation by carbonate and sulphate minerals, which drastically decreases the reservoir quality of the sandstones under study, was particularly important. Late diagenetic cementation by illite or the presence of matrix in the pore space caused porosity and permeability to decrease, but did not cause an extreme reduction, as indicated by relatively high reservoir classifications of 2 and 3.

The presence of illite in the pore space is mostly affected by the $R Q$ ratio of aeolian sandstones. The fact that not all aeolian sandstones are cemented by illite is an important issue. Moreover, cementation intensity varies from a few percent to several percent. This indicates that the illite cementation process could be selective, multistage, or both. Studies of illite in Rotliegend aeolian sandstones in Germany indicated that illite crystallisation is multistage and dependent on the presence of tectonic horst and trough (Zwingmann et al., 1998). Previous mineralogical studies of illites in the Polish Rotliegend Basin in- 


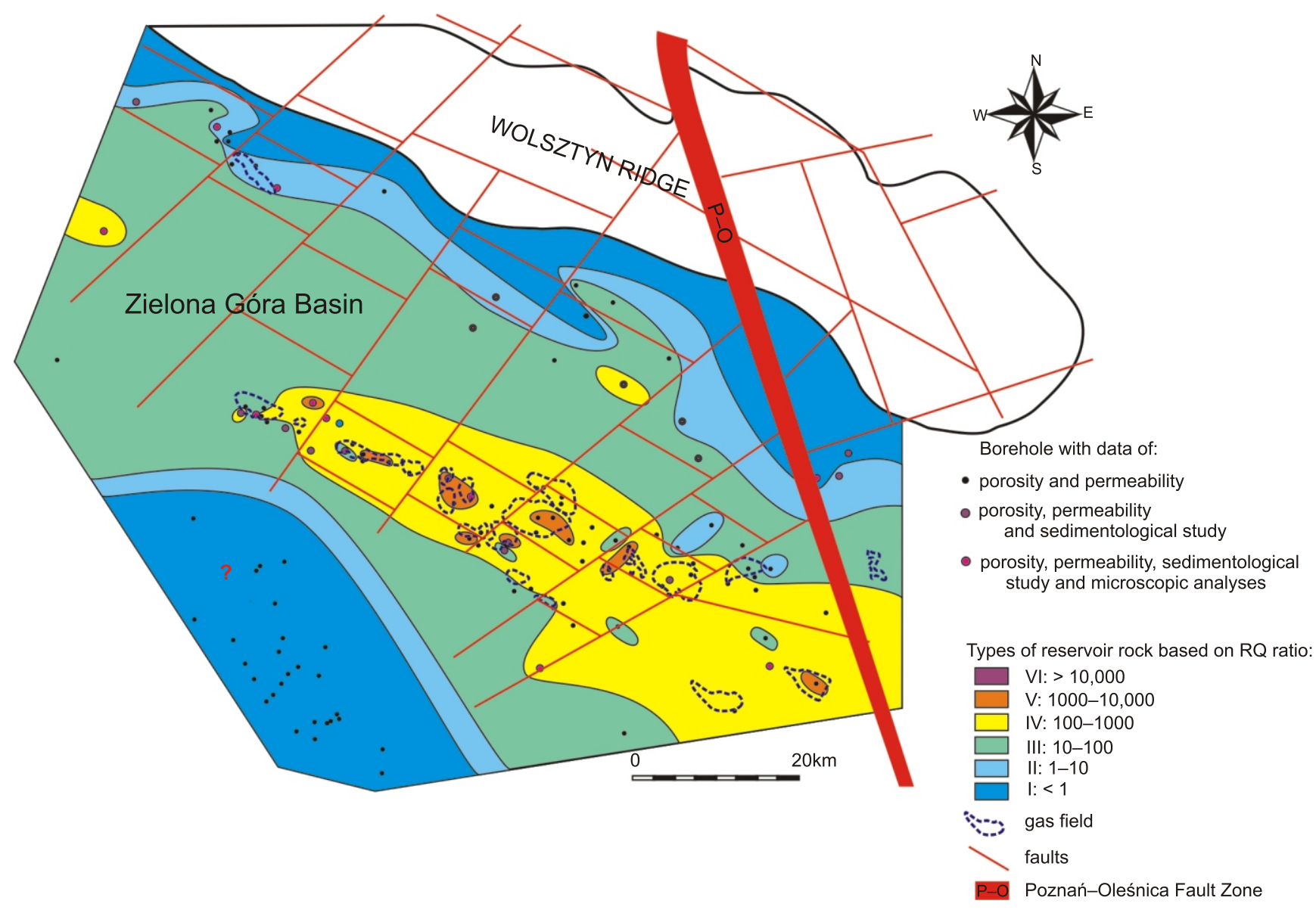

Fig. 10. Map showing the distribution of the mean value of the $R Q$ ratio for the topmost part $(50 \mathrm{~m})$ of the Upper Rotliegend and Weissliegend and distribution of synsedimentary Rotliegend faults

dicated that crystallisation of illite could be related to tectonic activity during the Jurassic period (Maliszewska and Kuberska, 2009). However, the effects of tectonic activity in the multistage crystallisation of illite have not been investigated in the Polish Rotliegend Basin, and this remains a topic for future research.

\section{DISCUSSION}

Sandstones from the Zielona Góra Basin and the Poznań Basin are characterized by different reservoir properties and different distributions. This is due to the different sedimentary conditions and diagenetic processes during burial in the two areas. Therefore, results from the Poznań Basin cannot be directly used in the Zielona Góra Basin.

The results obtained did not confirm that burial processes were the main factor differentiating reservoir properties in the Zielona Góra Basin. Probably, local factors influencing sandstone lithology, such as mineral composition of the grain framework, grain sorting, or presence of matrix, exerted more control over the reservoir properties of sandstones than burial processes.

Often sandstones occurring in the lower parts of the profiles were more compacted. It should be noted that the sandstone lithology of the lower parts of the profiles is different from that of the sandstones occurring above them. This applies to both aeolian and fluvial sandstones.

Aeolian sandstones occurring in the lower parts of the profiles were formed in the initial stage of erg formation (Kiersnowski, 1997). These sandstones are characterized by lower mineral maturity of the grain framework (quartz grains are fewer, lithoclasts and feldspar more abundant) than the aeolian sandstones present in the upper parts of the profiles, which were created during maximum erg development. Differentiation of grain mineral composition and the degree of sorting resulted in varying sandstone resistance to compaction. Hence, sandstones occurring deeper were more strongly compacted than sandstones located higher in the profile, but this does not indicate depth of burial.

Fluvial sandstones can also be analysed. The lower parts of the fluvial sandstone profiles are associated with the source areas. These sandstones are characterized by high matrix content in the pore space and poor grain sorting. However, in the upper part of the profile, fluvial sandstones often formed in alternation with aeolian sandstones (fluvial redeposition of aeolian sands). Therefore, the matrix content is lower and increases the degree of grain sorting, and the fluvial sandstones in the upper part of the profile are characterized by a higher resistance to compaction than those located below.

Differentiation of compaction intensity probably took place in the early stages of burial. Maximum burial of Rotliegend in the Zielona Góra Basin was approximately $3 \mathrm{~km}$ (Karnkowski, 1999). The largest subsidence took place in the Late Permian and Early Triassic (Karnkowski, 1999; Lamarche and ScheckWenderoth, 2005), when Rotliegend sandstones were rapidly buried to approximately $2 \mathrm{~km}$ depth. This step could have led to a different character of compaction in the sandstone profiles, which depended on sandstone lithology, but also on the content of early diagenetic cements. Therefore, Weissliegend sandstones with sulphate and carbonate cements are characterized by much lower compaction intensity than other sandstones. 


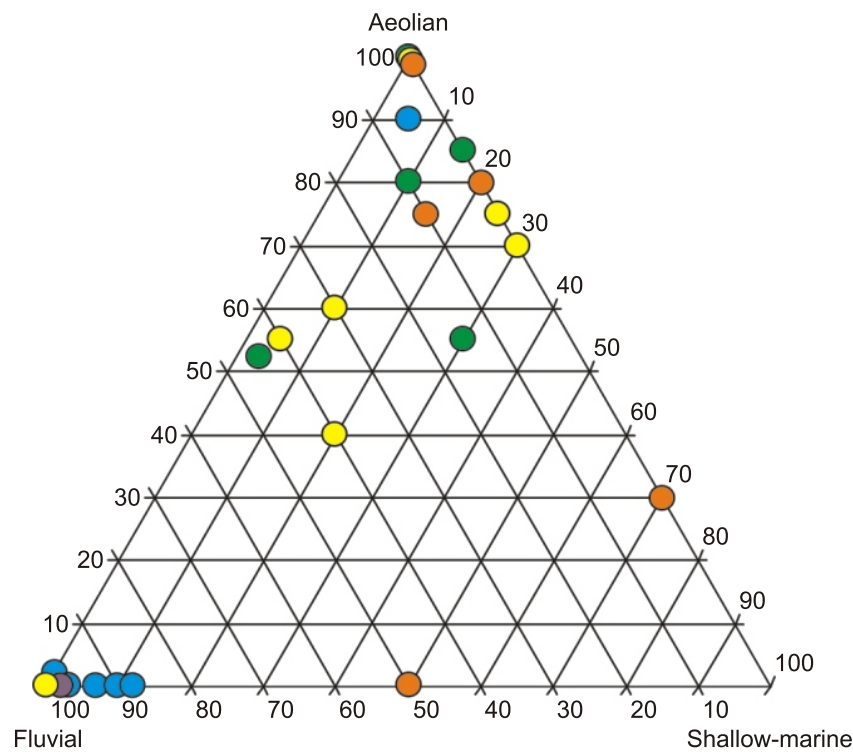

Types of reservoir rock based on $\mathrm{RQ}$ parameter:

$$
\begin{aligned}
& \text { Type V (RQ 1000-10,000) } \\
& \text { O Type IV (RQ 100-1000) } \\
& \text { O Type III (RQ 10-100) } \\
& \text { Type II (RQ 1-10) } \\
& \text { Type I (RQ<1) }
\end{aligned}
$$

Fig. 11. Distribution of the $R Q$ ratio with regard to percentage content of fluvial, aeolian and shallow-marine deposits in the sections for the topmost part $(50 \mathrm{~m})$ of the Upper Rotliegend and Weissliegend

The Poznań Basin is characterized by much greater thicknesses of aeolian sandstones and less diversity of aeolian sandstones (dominated by dune sandstones). There is an observed upward trend in the depth of burial of sediments towards the north, which is clearly associated with an increase in sandstone compaction intensity and a deterioration of reservoir properties. However, it should not be ignored that in the central part of the Rotliegend Basin, aeolian sedimentation had a different character than near Wolsztyn Ridge. This difference could lead to differing sandstone petrology and lower compaction resistance. However, this problem has not been previously studied.

\section{CONCLUSIONS}

Gas reservoirs in the Zielona Góra Basin are located within a wide area dominated by aeolian sandstones, which to the west pass into an area dominated by fluvial sandstones. Analysis of the variability of reservoir properties with regard to sedimentary conditions and microscopic observations made it possible to state that cementation was the most important process influencing the reservoir properties of sandstones. The varying compaction intensity in sandstones was found to be more strongly related with sandstone lithology and the presence of early diagenetic cements in sandstones than the depth of sandstone occurrence.

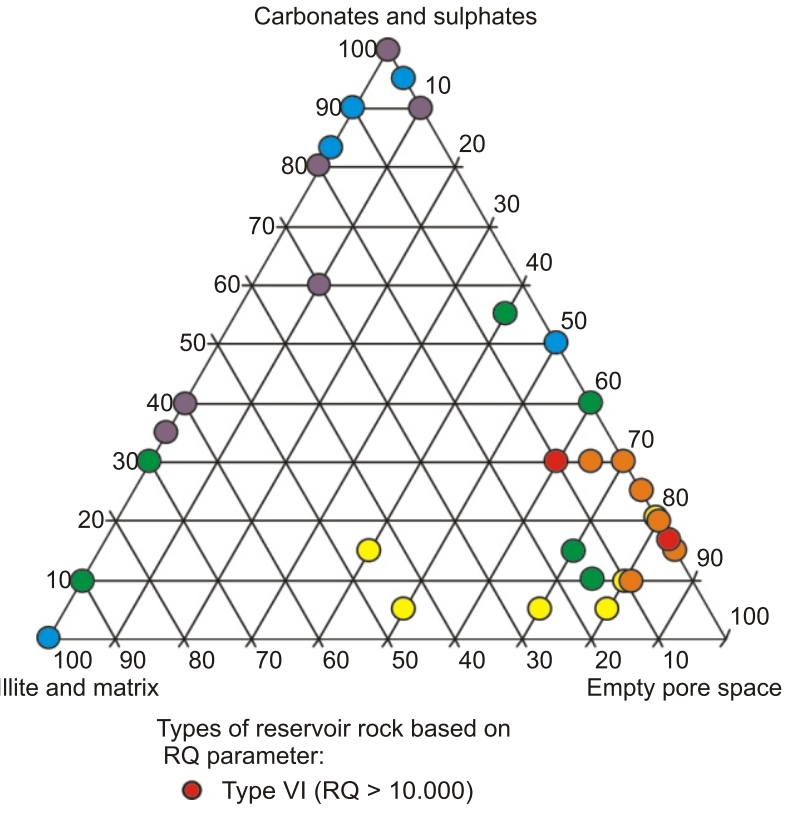

Fig. 12. Distribution of the $R Q$ ratio with regard to the type of the pore space filling in sandstones

Other explanations as in Figure 11

Cementation took place in several stages, of which the most important was early diagenetic cementation by carbonate and sulphate minerals, which were formed due to infiltration during the Zechstein transgression. Infiltration by Zechstein marine waters caused partial or complete restriction of the naturally good porosity and permeability of the sandstones under study. Later stages of diagenesis were probably linked with selective or multistage cementation of meshwork illite, which caused the patchy distribution of the currently observed reservoir quality of the rocks. It should be pointed out that illite cementation did not cause extreme reductions of porosity and permeability, but only reduced their values. Interpretation of the distribution of the $R Q$ ratio (porosity and permeability ratio) made it possible to distinguish areas with best and worst reservoir quality in the topmost $50 \mathrm{~m}$ of the Zielona Góra Basin, which in turn enabled designation of potential prospecting areas and may serve to interpret the variability of reservoir properties within presently exploited reservoirs. Parts of the gas reservoirs in the Zielona Góra Basin lie within two or even three reservoir classes (Fig. 10), as evidenced by the complex diagenetic processes in the sandstones. This indicates that gas also occurs in rocks with poor reservoir properties. This is an important clue for future research, not only in the Zielona Góra Basin, but also in the whole Polish Rotliegend Basin.

One advantage of the $R Q$ ratio is that it does not require analysis of two independent maps of porosity and permeability. The $R Q$ ratio is not restricted to the search for conventional hydrocarbons. It may also be helpful in determining the presence of tight rocks, identifying migration routes for gases and fluids, or searching for reservoir rocks as geothermal water sources and for underground storage of $\mathrm{CO}_{2}$.

Acknowledgments. This research was supported by the Institute of Geochemistry, Mineralogy, and Petrology, Warsaw University (grant IGMiP-36-2013). The author would like to thank the reviewers: I. Moeck, R. Gaupp and H. Kiersnowski for their detailed and constructive remarks and valuable com- 
ments, which have significantly improved the paper. I also thank P.H. Karnkowski, A. Maliszewska, P. Roniewicz and $P$. Such for the ability to discuss my results during my Ph.D. studies and T. Peryt for his remarks on the article. Polskie Górnictwo Naftowe i Gazownictwo S.A. has kindly provided geological information and Z. Mikołajewski and A. Buniak from the Zielona Góra Branch of the Polskie Górnictwo Naftowe i Gazownictwo S.A. have helped in the implementation of the research.

\section{REFERENCES}

Amthor J.E., Okkerman J. (1998) Influence of early diagenesis on reservoir quality of Rotliegende sandstones, Northern Netherlands. AAPG Bulletin, 82: 2246-2265.

Bała M., Jarzyna J. (2004) Zależność między porowatością i przepuszczalnością w skałach zbiornikowych z uwzględnieniem współczynnika charakteryzującego przestrzeń porową (in Polish). Prace Instytutu Nafty i Gazu, 150: 275-279.

Beard D.C., Weyl P.K. (1973) Influence of texture on porosity and permeability of unconsolidated sand. AAPG Bulletin, 57: 349-369.

Bjørlykke K., Ramm M., Saigal G.C. (1989) Sandstone diagenesis and porosity modification during basin evolution. Geologische Rundschau, 78: 243-268.

Buniak A. (1999) Środowiska depozycji i rozwój sedymentacji górnego czerwonego spągowca w północnej części monokliny przedsudeckiej (rejon Poznań-Pniewy) (in Polish). Przegląd Geologiczny, 47: 465.

Buniak A., Mikołajewski Z., Protas A. (1999) Depositional environment and petrology of Rotliegend deposits from the Unisław-Wałdowo Królewskie region (in Polish with English summary). Geologos, 4: 5-27.

Buniak A., Kuberska M., Kiersnowski H. (2009) Petrographical-petrophysical characteristics of the Rotliegend eolian sandstones of the Siekierki-Winna Góra Zone (the Poznań region) in the aspect of search for gas trapped in deposits (in Polish with English summary). Przegląd Geologiczny, 57: 328-334.

Cade C.A., Evans I.J., Bryant L. (1994) Analysis of permeability controls: a new approach. Clay Minerals, 29: 491-501.

Corbett P.W.M., Potter G.K. (2004) Petrotyping: a basemap and atlas for navigating through permeability and porosity data for reservoir comparison and permeability prediction. International Symposium of the Society of Core Analysts, 5-9 October, 2004, Abu Dhabi, UAE: 385-395.

Doornenbal J.C., Stevenson A.G., eds. (2010) Petroleum Geological Atlas of the Southern Permian Basin Area. EAGE Publications b.v. (Houten).

Ethier V.G., King H.R. (1991) Reservoir quality evaluation from visual attributes on rock surfaces: methods of estimation and classification from drill cuttings or cores. Bulletin of Canadian Petroleum Geology, 39: 233-251.

Evans J., Cade C., Bryant S. (1997) A geological approach to permeabilty prediction in clastic reservoirs. AAPG Memoir, 69: 91-101.

Gaupp R. (1997) Diagenesis types and their application in diagenesis mapping. Zentralblatt für Geologie und Paläontologie, Teil I (11/12): 1183-1199.

Gaupp R., Okkerman J.A. (2011) Diagenesis and reservoir quality of Rotliegend sandstones in the Northern Netherlands. SEPM Special Publication, 98: 193-228.

Gaupp R., Matter A., Platt J., Ramseyer K., Walzebuck J. (1993) Diagenesis and fluid evolution of deeply buried Permian (Rotliegende) gas reservoirs, Northwest Germany. AAPG Bulletin, 67: 280-312.

Glennie K. W., ed. (1990) Introduction to the Petroleum Geology of the North Sea, London.
Glennie K.W., Buller A.T. (1983) The Permian Weissliegend of NW Europe: the partial deformation of eolian dune sands caused by the Zechstein transgresion. Sedimentary Geology, 35: 43-81.

Gluyas J., Leonard A. (1995) Diagenesis of the Rotliegend Sandstone: the answer ain't blowin' in the wind. Marine and Petroleum Geology, 12: 491-497.

Gregosiewicz Z., Protas A. (1997) Facje, diageneza a własności zbiornikowe piaskowców czerwonego spagowca rejonu złoża Radlin (in Polish). Nafta-Gaz, 57: 375-387.

Hogg A.J.C., Mitchell A.W., Young S. (1996) Prediction of porosity in compacted sands. AAPG Memoir, 69: 1-15.

Houseknecht D.W. (1987) Assessing the relative importance of compaction processes and cementation to reduction of porosity in sandstones. AAPG Bulletin, 71: 633-642.

Jarzyna J., Puskarczyk E., Bała M., Papiernik B. (2009) Variability of the Rotliegend sandstones in the Polish part of the Southern Permian Basin - permeability and porosity relationships. Annales Societatis Geologorum Poloniae, 79: 13-26

Jerzykiewicz T., Kijewski P., Mroczkowski J., Teisseyre A.K. (1976) Origin of the Weissliegendes deposits in the Fore-Sudetic Monocline (in Polish with English summary). Geologia Sudetica, 11: 57-330.

Karnkowski P. (1999) Oil and Gas Deposits in Poland. Geosynoptics Society, Kraków.

Karnkowski P.H. (1986) The nature of Zechstein transgression versus origin of Weissliegendes in the Wielkopolska area (northern Fore-Sudetic Monocline, western Poland (in Polish with English summary). Geologia Sudetica, 21: 101-122.

Karnkowski P.H. (1987) Facies analysis of Wielkopolska subgroup (Upper Rotliegend) in the northern part of the Fore-Sudetic (in Polish with English summary). Przegląd Geologiczny, 35: 187-192.

Karnkowski P.H. (1994) Rotliegend lithostratigraphy in the central part of the Polish Permian Basin. Geological Quarterly, 38 (1): 27-42.

Karnkowski P.H. (1999) Origin and evolution of the Polish Rotliegend Basin. Polish Geological Institute, Special Papers, 3: 1-93.

Karnkowski P.H. (2007) Permian Basin as a main exploration target in Poland (in Polish with English summary). Przegląd Geologiczny, 55: 1003-1015.

Kiersnowski H. (1997) Depositional development of the Polish Upper Rotliegend Basin and evolution of its sediment source areas. Geological Quarterly, 41 (4): 433-456.

Kiersnowski H., Buniak A. (2006) Evolution of the Rotliegend basin of northwestern Poland. Geological Quarterly, 50 (1): 119-137.

Kiersnowski H., Buniak A., Kuberska M., Srokowska-Okońska A. (2010a) Tight gas accumulations in Rotliegend sandstones of Poland (in Polish with English summary). Przegląd Geologiczny, 58: 335-346.

Kiersnowski H., Peryt T.M., Buniak A., Mikołajewski Z. (2010b) From the intra-desert ridges to the marine carbonate island chain: middle to late Permian (Upper Rotliegend-Lower Zechstein) of the Wolsztyn-Pogorzela High, west Poland. Geological Journal, 45: 319-335. 
Kotarba M.J., Peryt T.M., Kosakowski P., Więcław D. (2006) Organic geochemistry, depositional history and hydrocarbon generation modelling of the Upper Permian Kupferschiefer and Zechstein Limestone strata in south-west Poland. Marine and Petroleum Geology, 23: 371-386.

Kuberska M. (2004) Diagenesis of the Rotliegend rocks in the Szczecinek-Bydgoszcz area (Western Pomerania) (in Polish with English summary). Biuletyn Państwowego Instytutu Geologicznego, 411: 87-168.

Kwolek K., Buniak A. (2004) Charakterystyka geologiczna potencjał akumulacyjny utworów górnego czerwonego spągowca w rejonie Poznań-Ostrów Wielkopolski (in Polish) Konferencja Naukowo-Techniczna „Basen permski Niżu Polskiego - czerwony spągowiec, budowa i potencjał zasobowy", 23 kwiatnia 2004, Piła.

Lamarche J., Scheck-Wenderoth M. (2005) 3D structural model of the Polish Basin. Tectonophysics, 397: 73-91.

Levorsen A.I. (1967) Geology of Petroleum. Freeman, San Francisco.

Maliszewska A. (1997) Wiek K/Ar włóknistego illitu z piaskowców czerwonego spągowca Wielkopolski (in Polish). In: Datowanie minerałów i skał, IV Ogólnopolska Sesja Naukowa, Lublin: 50-55.

Maliszewska A., Kuberska M. (1996) Cementacja piaskowców czerwonego spągowca a ich porowatość i przepuszczalność (in Polish). Nafta-Gaz, 9: 365-373.

Maliszewska A., Kuberska M. (2009) Isotopic investigations of diagenetic illite of Rotliegend sandstones from theWielkopolska and Western Pomerania regions (in Polish with English summary). Przegląd Geologiczny, 57: 322-327.

Miall A.D. (1978) Lithofacies types and vertical profile models in braided river deposits: a summary. Memoir, 5: 597-604.

Michalik M. (1996) Zróżnicowanie procesów krystalizacj diagenetycznych illitów w piaskowcach permu w niecce północnosudeckiej i na monoklinie przedsudeckiej (in Polish). III Ogólnopolska Sesja Naukowa „Datowanie minerałów i skał w oparciu o rozpad promieniotwórczy potasu-40”, Lublin: 45-50.

Michalik M. (2000) Evolution of diagenetic fluids in the Weissliegend sandstones from the southwestern margin of the Polish Rotliegend Basin. Prace Specjalne PTMiN, 17: 218-220.

Michalik M. (2001) Diagenesis of the Weissliegend sandstones in the south-west margin of the Polish Rotliegend Basin. Prace Mineralogiczne, 91: 3-171.

Muszyński M., Rydzewska W. (1986) Diagenetic changes in Saxonian sediments of the middle Fore-Sudetic Monocline and their impact on reservoir properties (in Polish with English summary). Przegląd Geologiczny, 34: 509-514.

Nemec W., Porębski S.J. (1977) Weissliegendes sandstones: a transition from fluvial-eolian to shallow-marine sedimentation (Lower Permian of the Fore-Sudetic Monocline). 1. Sedimentary structures and textural differentiation. Rocznik Polskiego Towarzystwa Geologicznego, 47: 387-418.

Nikishin A.M., Ziegler P.A., Abbott D., Brunet M.F., Cloetingh S. (2002) Permo-Triassic intraplate magmatism and rifting in Eurasia: implications for mantle plumes and mantle dynamics. Tectonophysics, 351: 3-39.

Papiernik B., Górecki W., Pasternacki A. (2010) Preliminary results of 3D modeling of petrophysical parameters for tight gas prospecting in the Polish Rotliegend Basin (in Polish with English summary). Przegląd Geologiczny, 58: 352-364.
Peryt D., Peryt T.M., Raczyński P., Chłódek K. (2012) Foraminiferal colonization related to the Zechstein (Lopingian) transgression in the western part of the Wolsztyn Palaeo-Ridge area, Western Poland. Geological Quarterly, 56 (3): 529-546.

Pettijohn F.J., Potter P.E., Siever R. (1972) Sand and Sandstones. Springer-Verlag, New York.

Pokorski J., Kiersnowski H. (1999) Wybrane elementy ewolucji basenu czerwonego spagowca na podstawie analizy tektonicznej i litofacjalnej (in Polish). Przegląd Geologiczny, 47: 464.

Poprawa P., Kiersnowski H. (2008) Potential for shale gas and tight gas exploration in Poland (in Polish with English summary). Biuletyn Państwowego Instytutu Geologicznego, 429: 145-152.

Poprawa P., Kiersnowski H. (2010) Tight gas accumulations in Rotliegend sandstones of Poland (in Polish with English summary). Biuletyn Państwowego Instytutu Geologicznego, 439: 173-180.

Poszytek A. (2006) Zmienność właściwości zbiornikowych górnego czerwonego spągowca w centralnej części monokliny przedsudeckiej (in Polish). Nafta-Gaz. 62: 559-564.

Rochewicz A. (1980) Wpływ procesów illityzacji i chlorytyzacji na własności kolektorskie piaskowców czerwonego spągowca SW Polski (in Polish). Archiwum Mineralogiczne, 36: 55-61.

Such P. (1996) Model fizyczny przestrzeni filtracji basenu czerwonego spągowca (in Polish). Prace Instytutu Nafty i Gazu, 88.

Such P., Maliszewska A., Leśniak G. (2000) Właściwości filtracyjne utworów czerwonego spągowca a jego wykształcenie facjalne (in Polish). Prace Instytutu Nafty i Gazu, 103: 5-49.

Such P., Leśniak G., Słota M. (2010) Quantitative porosity and permeability characterization of potential Rotliegend tight gas reservoirs (in Polish with English summary). Przegląd Geologiczny, 58: $347-351$.

Sweet M.L. (1999) Interaction between aeolian, fluvial and playa environments in the Permian Upper Rotliegend Group, UK southern North Sea. Sedimentology, 46: 171-187.

Szwarc R., Kiersnowski H. (1999) Rozwój sedymentacji osadów czerwonego spągowca w SE części polskiego basenu permskiego (in Polish). Przegląd Geologiczny, 47: 469-470.

Tiab D., Donaldson E.C. (2004) Petrophysics. Gulf Publishing Company, Houston.

Weihe T. (1997) Sedimentologie und Fazies des Rotliegenden (unteres Perm) nördlich des Wolsztyn-Hochs, Westpolen, im Spiegel der Beckenentwicklung. Selbstverlag der Geowissenschaftlichen Institute der Technische Universität, Clausthal.

Wagner R., Peryt T.M. (1997) Possibility of sequence stratigraphic subdivision of the Zechstein in the Polish Basin. Geological Quarterly, 41 (4): 457-474.

Wolnowski T. (2004) Prognoza zasobności czerwonego spągowca w basenie permskim niżu polskiego w świetle nowych technik poszukiwawczych (in Polish). Konferencja NaukowoTechniczna „Basen permski Niżu Polskiego - czerwony spągowiec, budowa i potencjał zasobowy", 23 kwietnia 2004, Piła.

Ziegler P.A. (1990) Geological Atlas of Western and Central Europe. Shell Int. Petr. Maa.B.V.

Zwingmann H., Clauer N., Gaupp R. (1998) Timing of fluid flow in a sandstone reservoir of the North-German Rotliegend (Permian) by K-Ar dating of related hydrothermal illite. Geological Society Special Publications, 144: 91-106. 